\title{
Prey occurRence in THE STOMACH CONTENTS of four small cetacean species in Peru
}

\author{
Ignacio García-Godos ${ }^{1, *}$, Koen Van Waerebeek ${ }^{2}$, Julio C. Reyes ${ }^{3}$, \\ Joanna Alfaro-Shigueto ${ }^{4,5}$ and Milena Arias-Schreiber ${ }^{6}$
}

\begin{abstract}
Aвstract: The diets of long-beaked common dolphins Delphinus capensis ( $\mathrm{n}=117)$, dusky dolphins Lagenorhynchus obscurus $(\mathrm{n}=72)$, Burmeister's porpoises Phocoena spinipinnis $(\mathrm{n}=69)$ and offshore common bottlenose dolphins Tursiops truncatus $(\mathrm{n}=22)$ were determined based on the analysis of the stomach contents collected from animals landed in ports along the Peruvian central coast and from Marcona, in southern Peru, during 1987-1993. The number of prey ingested was obtained by counting the number of fish otoliths and cephalopod mandibles (beaks). Only fish could be identified to species level. Long-beaked common dolphins fed mainly on Peruvian anchovy Engraulis ringens (70.0\% by number), Panama lightfish Vincigerria lucetia $(7.8 \%)$ and slimtail lanternfish Lampanyctus parvicauda (6.7\%). Dusky dolphins consumed mainly anchovies $(49.7 \%, 16.8 \%)$, slimtail lanternfish $(23.6 \%, 0.1 \%)$, Inca scad Trachurus murphyi $(17.1 \%, 0 \%)$ and mote sculpin Normanichthys crockeri $(0 \%, 76.0 \%)$ off the central Peruvian coast and Marcona, respectively. In the same areas, Burmeister's porpoises fed mainly on anchovy $(88.9 \%, 77.6 \%)$, silverside Odontesthes regia $(6.5 \%, 0 \%)$, mote sculpin $(0 \%, 8.1 \%)$ and South Pacific hake Merluccius gayi $(0.6 \%$, 7.9\%). Offshore common bottlenose dolphins consumed mainly slimtail lanternfish (39.2\%), barracuda Sphyraena sp. (13.5\%) and Peruvian pilchard Sardinops sagax (13.3\%). The diversity indices of the diet and temporal shifts in the main prey suggest an opportunistic feeding strategy for the four cetacean species studied, which take advantage of the locally most available epipelagic and mesopelagic schooling fish. Cluster analysis shows high similarity in their diets, with these four marine top predators being able to optimally exploit the high productivity of the Peruvian upwelling ecosystem.
\end{abstract}

KEYwords: small cetaceans; food; prey; habitat; feeding ecology, Peru, Southeast Pacific.

\section{Introduction}

The Peruvian upwelling system is one of the most productive ecosystems in the world (Ryther, 1969; Duffy, 1994; Bakun and Weeks, 2008), supporting a great variety of fish species and fisheries that provide food for humans and prime material for the animal feed industry. Despite intense exploitation, our knowledge of the trophic relationships within this ecosystem is limited (Pauly and Tsukayama, 1987), with the highest research efforts focused on the Peruvian anchovy Engraulis ringens.

The Peruvian anchovy is the most heavily exploited marine resource in Peru and its industrial fishery for fish meal and oil is the largest single species fishery in the world (Whitehead et al. 1988, Jahncke et al. 2004; Bakun and Weeks, 2008). Over-exploitation in the early 1970s, in combination with a severe El Niño event caused the collapse of anchovy populations and their fishery, whose effects are experienced even decades after (Jordán, 1982; Jahncke et al., 2004). Together with the anchovy its predators also collapsed; the most conspicuous case was that of Peruvian guanoproducing seabirds, whose populations declined dramatically (Duffy et al., 1984; Jahncke et al., 2004). Other marine predators, including small cetaceans, could also have been negatively affected by the anchovy collapse. However, no information is available due to the lack of studies during those years.

Research on the exploitation of cetaceans by artisanal and industrial fisheries in Peru started in late 1984 by scientists of the Peruvian Centre for Cetacean Research (CEPEC) and associates (e.g. Read et al., 1988; Van Waerebeek and Reyes, 1990; García-Godos, 1993; Van Waerebeek et al., 1994a, b). The mortality of small cetaceans caused by these fisheries in 1985 and 1994 was estimated to range between 10000 and 17500 individuals (Read et al., 1988; Van Waerebeek and Reyes, 1994), including by-catch in gillnet and purse-seine operations and animals taken directly with large-mesh gillnets or hand-thrown harpoons. Of the 32 cetacean species recorded to date in Peru (Arias-Schreiber, 1996), these takes affected mainly four species: the dusky dolphin Lagenorhynchus obscurus, the long-beaked common dolphin Delphinus capensis, the common bottlenose dolphin Tursiops truncatus (both offshore and inshore forms sensu Van Waerebeek et al., 1990; Sanino et al., 2004) and the Burmeister's porpoise Phocoena spinipinnis. These species have been protected by Peruvian legislation since 1990, but with low impact on mortality rates until 1996 when law enforcement was implemented more strictly after a massive public campaign for their conservation. Nowadays the fisheryrelated mortality of cetaceans may have declined significantly, although a black market for dolphin meat persists (García-Godos, 2007).

\footnotetext{
${ }^{1}$ Peruvian Centre for Cetacean Research (CEPEC).

*Corresponding author, e-mail: ag_godos@yahoo.com. Avenida F. Mariátegui 129, Dpt. 403, Lima 11, Peru.

${ }^{2}$ Peruvian Centre for Cetacean Research (CEPEC), Museo de Delfines, Pucusana, Lima 20, Peru. E-mail: cepec@speedy.com.pe.

${ }^{3}$ Áreas Costeras y Recursos Marinos (ACOREMA), Calle San Francisco 253, 201-B, Pisco, Peru. E-mail: acoremabiodiverso@yahoo.com.

${ }^{4}$ Pro Delphinus, Calle Octavio Bernal 572-5, Lima 11, Peru.

${ }^{5}$ University of Exeter, Cornwall Campus, Center for Ecology and Conservation, Penryn, Cornwall TR10 9EZ, UK.

${ }^{6}$ Center for Tropical Marine Ecology, Fahrenheitstrasse 6, 28359, Bremen, Germany.
} 
Despite the intense exploitation of small cetaceans in the late 1980s and early 1990s, there is only fragmentary knowledge on the natural history of these species, with the exception of the dusky dolphin (e.g Van Waerebeek, 1992a,b; Van Waerebeek and Read, 1994; McKinnon, 1994). Pauly and Tsukayama (1987) argued that the lack of knowledge of the diet of small cetaceans was a limiting factor for designing a model for the management of fisheries in the Peruvian-Chilean region. Here we present an analysis of the diet of the four main small cetacean species caught in fishing operations from central and southern ports of Peru over the past two decades, with the focus on fish prey. Comparisons between their diets are discussed as to define their respective ecological roles in the Peruvian upwelling ecosystem.

\section{Material and Methods}

\section{Samples}

Stomach contents of 280 small cetaceans landed by artisanal fishermen in the Peruvian ports of Ancón, Pucusana, Cerro Azul and San Juan de Marcona (further referred to as Marcona) (Figure 1) were collected and examined by the authors between 1987 and 1993. The samples from Marcona were collected by MAS during port monitoring for the Punta San Juan Project (see Majluf et al., 2002). The cetacean sample consisted of stomach contents of long-beaked common dolphins $(n=117)$, dusky dolphins $(n=72)$, offshore common bottlenose dolphins $(\mathrm{n}=22)$ and Burmeister's porpoises $(n=69)$. All prey items sampled from stomach contents in the ports of Pucusana, Cerro Azul and Ancón were pooled as from single stocks named 'central coast of Peru', comprising a coastal strip of ca. $160 \mathrm{~km}$ long (Figure 1). Indeed, the marine ecosystem of the central coast of Peru is practically homogeneous (Brainard and McLain, 1987; Peña et al., 1989).

Stomachs (fore, main and pyloric) of freshly landed cetaceans were dissected at the local fish markets and their complete contents were sieved and washed over plastic containers. Hard items including otoliths and squid beaks were recovered. Otoliths were stored dry, while squid beaks were kept in $70 \%$ ethanol. All material and field data are deposited at the Museo de Delfines, CEPEC, Pucusana. Where possible otoliths were morphologically identified to species by the first author following García-Godos (2001) and reference collections. Squid beaks could not be identified to species due to the lack of a reference collection. However, pooled, they were accounted for in the general prey composition. Also because of their low occurrence cephalopods were not further analyzed, but were considered as a single item in the interspecies cluster analysis of the diet (see below).

\section{Data analysis}

Samples were grouped by sampling periods determined by the season and the year they were collected (the 'sampling period'). Main food parameters studied included the 'frequency of occurrence' (FO), defined as the percentage of occurrence $(\% \mathrm{FO})$ of a particular prey species in the sample of stomach contents for each cetacean species, and the 'prey composition by number' (\% Num) as the percentage of the total number of all fish prey individuals for each cetacean species. The number of individual fishes found in each stomach was determined as the number of sagittae otoliths divided by two (Frost and Lowry, 1980; McKinnon, 1994).

To verify differences in the diet with respect to reproductive status of the cetaceans, the sample was divided into five categories: 1) immature females; 2) resting adult females; 3 ) reproductive females (pregnant or lactating); 4) sexually immature males; and 5) adult males. Reproductive status was determined in the field based on the macroscopic examination of gonads and other reproductive organs (Van Waerebeek, 1992a; Van Waerebeek and Read, 1994). The frequency distribution of reproductive status per species is shown in Table 1.

Non-parametric statistics were used in the data analysis because of the heterogeneity of the sample and small sample sizes of sub-groups. To determine differences in the median percentage of prey consumption by number among seasons, reproductive status and diversity (see below), Kruskal-Wallis (KW), MannWhitney (MW) and Chi-square tests (Siegel, 1956) were applied. Mann-Whitney test was also used to determine apparent bias in the sample, probably caused by a more

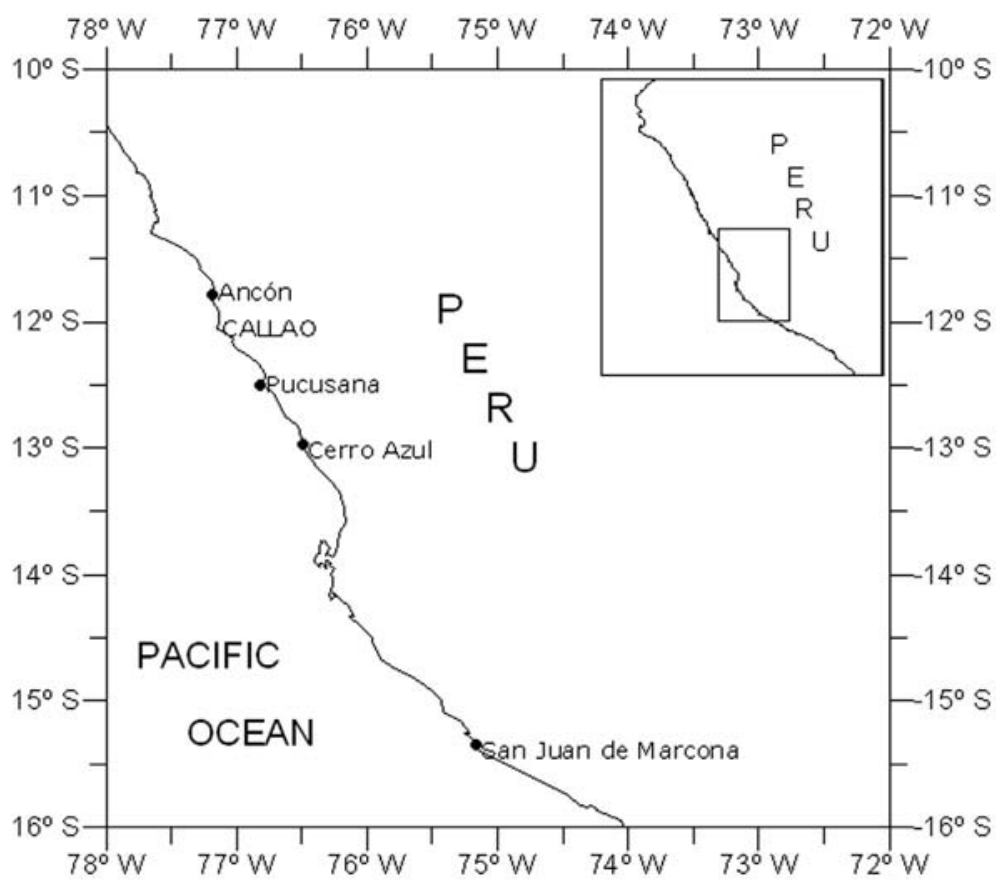

Figure 1. Sampling locations along the Peruvian coast 
intensive sampling in 1987. Spearman correlations were computed between the body length of cetaceans and both the number of prey species and number of individual prey items.

The trophic niche breadth was estimated for each species sampled using the Shannon and Wiener index of diversity $(\mathrm{H})$ as defined by Krebs (1989). The logarithmic base of this index is 2, therefore its units are bits and it ranges from zero to infinite. For a better interpretation of this index we used its standardized form $\left(\mathrm{H}_{\text {std }}\right)$ which ranges from zero to one (Krebs, 1989). To determine the level of similarity in the diet of the small cetaceans studied we used the Simplified Morisita's index of similarity (Krebs, 1989).

For a graphical view of diet diversification in the small cetacean community we ran a mean linkage hierarchical cluster analysis (Krebs, 1989) using the Morisita's simplified similarity index and the pooled ratio of prey species for each cetacean species. The level of overlap between the general consumption by small cetaceans and the landings of the pelagic industrial fishery was preliminarily estimated using the latter index. Fishery landings were taken from the statistics published by Niquen and Bouchón (1995).

\section{Results}

\section{Long-beaked common dolphin}

Food items of long-beaked common dolphins were mainly fish, comprising $98.7 \%$ of the prey (9828 individuals), while the remainder was composed of squids and crustaceans. From the 20 fish prey species observed, six were present in at least $10 \%$ of the pooled sample (Table 2). The Peruvian anchovy Engraulis ringens was the most important prey $(70 \%)$, followed by the Panama lightfish Vinciguerria lucetia (7.76\%) and the slimtailed lanternfish Lampanyctus parvicauda $(6.66 \%)$. The Peruvian anchovy was the most frequently consumed prey (81.51\% FO), followed by silverside Odontesthes regia (17.65\% FO), Peruvian pilchard Sardinops sagax (15.97\% FO), Inca scad Trachurus murphyi (15.97\% FO), South Pacific hake Merluccius gayi (14.29\% FO) and squids (11.76\% FO). No statistical difference was found in prey composition by number between 1987 and the whole period sampled $(\mathrm{MW}=185.00, \mathrm{P}>0.6)$, however significant differences existed in the consumption of anchovy $(\mathrm{KW}=14.042, \mathrm{P}<0.05, \mathrm{df}=6)$ and silverside $(\mathrm{KW}=24.498, \mathrm{P}<0.01, \mathrm{df}=6)$ among seven sampling periods with more than five stomach contents collected. For 1987, differences were found among seasons for anchovy (KW=9.541, $\mathrm{P}<0.05, \mathrm{df}=3)$, slimtailed lanternfish $(\mathrm{KW}=17.86, \mathrm{P}<0.001, \mathrm{df}=3)$, pearly lanternfish Myctophum nitidulum (KW=13.23, $\mathrm{P}<0.01, \mathrm{df}=3)$ and Panama lightfish $(\mathrm{KW}=18.416$, $\mathrm{P}<0.001, \mathrm{df}=3)$. The largest amount of anchovy consumed in 1987 was during summer and winter, while mesopelagic species like lightfish and slimtailed lanternfish showed higher consumption during autumn and spring of that year (Table 2).

Among reproductive status, no statistical differences were found in the median number of prey species (KW= 2.469, $\mathrm{P}=0.65, \mathrm{df}=4)$, in the number of prey consumed $(\mathrm{KW}=2.021, \mathrm{P}>0.7, \mathrm{df}=4)$ nor the median percentage of anchovy $(K W=4.527, \mathrm{P}>0.3, \mathrm{df}=4)$. The body length of dolphins was positively related to the number of prey species $(\mathrm{r}=0.243, \mathrm{n}=84, \mathrm{P}<0.05)$ and the number of prey ( $\mathrm{r}=0.283, \mathrm{n}=84, \mathrm{P}<0.01)$.

The standardized Shannon-Wiener index of diversity $\left(\mathrm{H}_{\text {std }}\right)$ obtained for the pooled sample was 0.397 (mean= 0.199, S.D. $=0.156, \mathrm{n}=14$ ). No statistical differences in the diversity of the diet were found among all sampling periods $\left(x^{2}=7.600, \mathrm{P}>0.8, \mathrm{df}=13\right.$; using $\mathrm{H}_{\max }$ as expected value: $\left.x^{2}=9.952, \mathrm{P}>0.5, \mathrm{df}=13\right)$. A higher diversity of diet was observed when different prey other than anchovy dominated the diet. During 1987, when mesopelagic fish dominated the diet, $\mathrm{H}_{\text {std }}$ was higher, 0.472 and 0.453 in autumn and spring, respectively (Table 2).

\section{Dusky dolphin}

The diet of the dusky dolphin in the central coast of Peru $(n=49$, Table 3$)$ consisted almost exclusively of fish, with 14 prey species (1815 prey individuals), the remainder $(0.11 \%)$ were squids. Anchovy was the main prey consumed by number $(49.70 \%)$, followed by the slimtail lanternfish (23.61\%), Inca scad (17.06\%), and Panama lightfish (3.52\%), among other species. Anchovy was also the most frequent prey species (71.43\% FO), followed by Inca scad (57.14\% FO), pilchard Sardinops sagax (20.41\% FO), silverside $(16.33 \% \mathrm{FO})$ and slimtail lanternfish (12.24\% FO).

Table 1. Categories of reproductive status in the sample of Peruvian small cetaceans examined for this study.

\begin{tabular}{|c|c|c|c|c|}
\hline \multirow{2}{*}{ REPRODUCTIVE STATUS } & \multicolumn{4}{|c|}{ SPECIES } \\
\hline & D.capensis & L. obscurus & T. truncatus & P.spinipinnis \\
\hline Q - immature & 22 & 4 & 2 & 3 \\
\hline 우 - resting adult & 3 & 3 & 2 & 3 \\
\hline 우 - reproductive & 5 & 8 & 1 & 7 \\
\hline$\sigma^{\prime}$ - immature & 35 & 3 & 3 & 15 \\
\hline$\sigma^{\prime}$ - adult & 19 & 18 & 9 & 13 \\
\hline
\end{tabular}




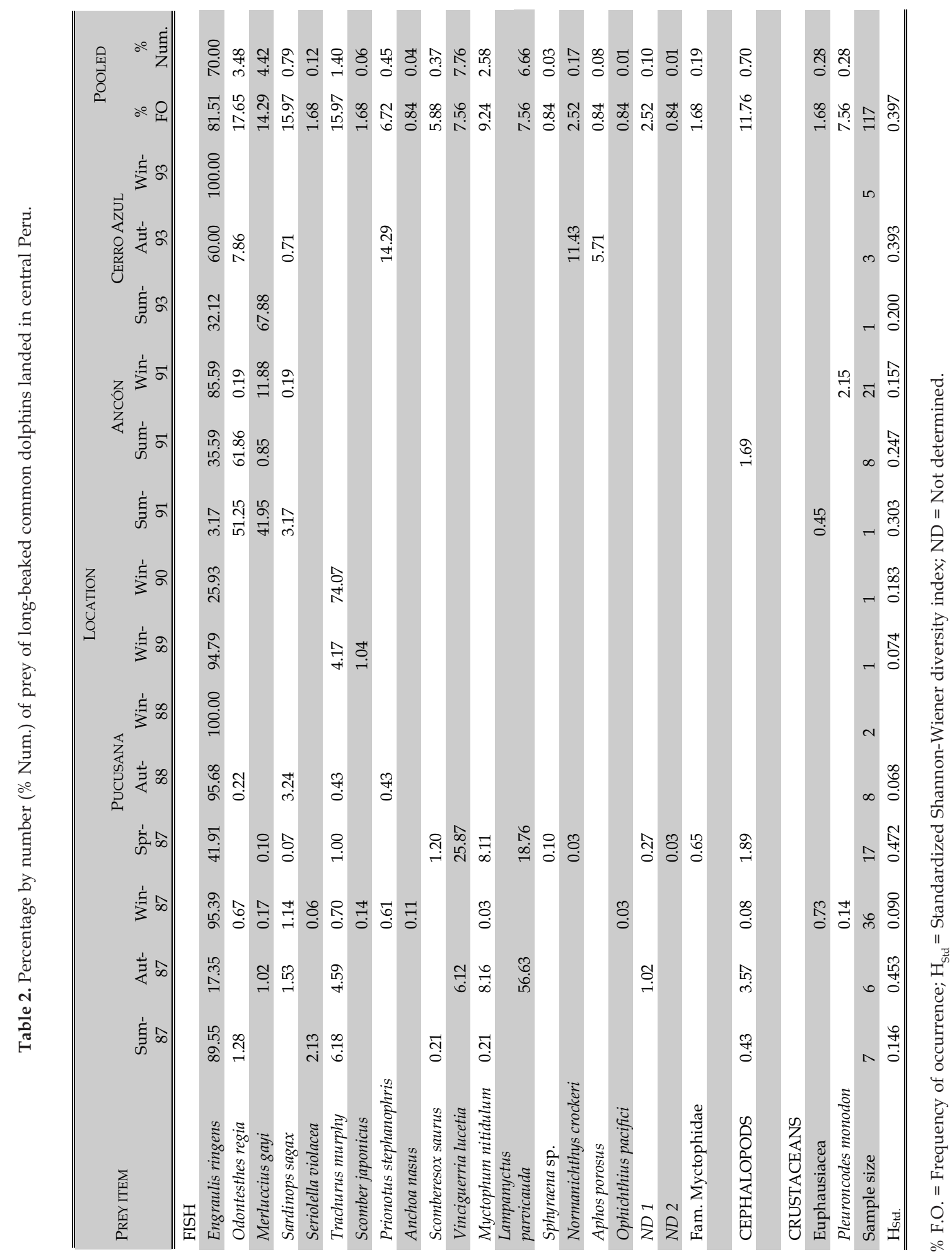




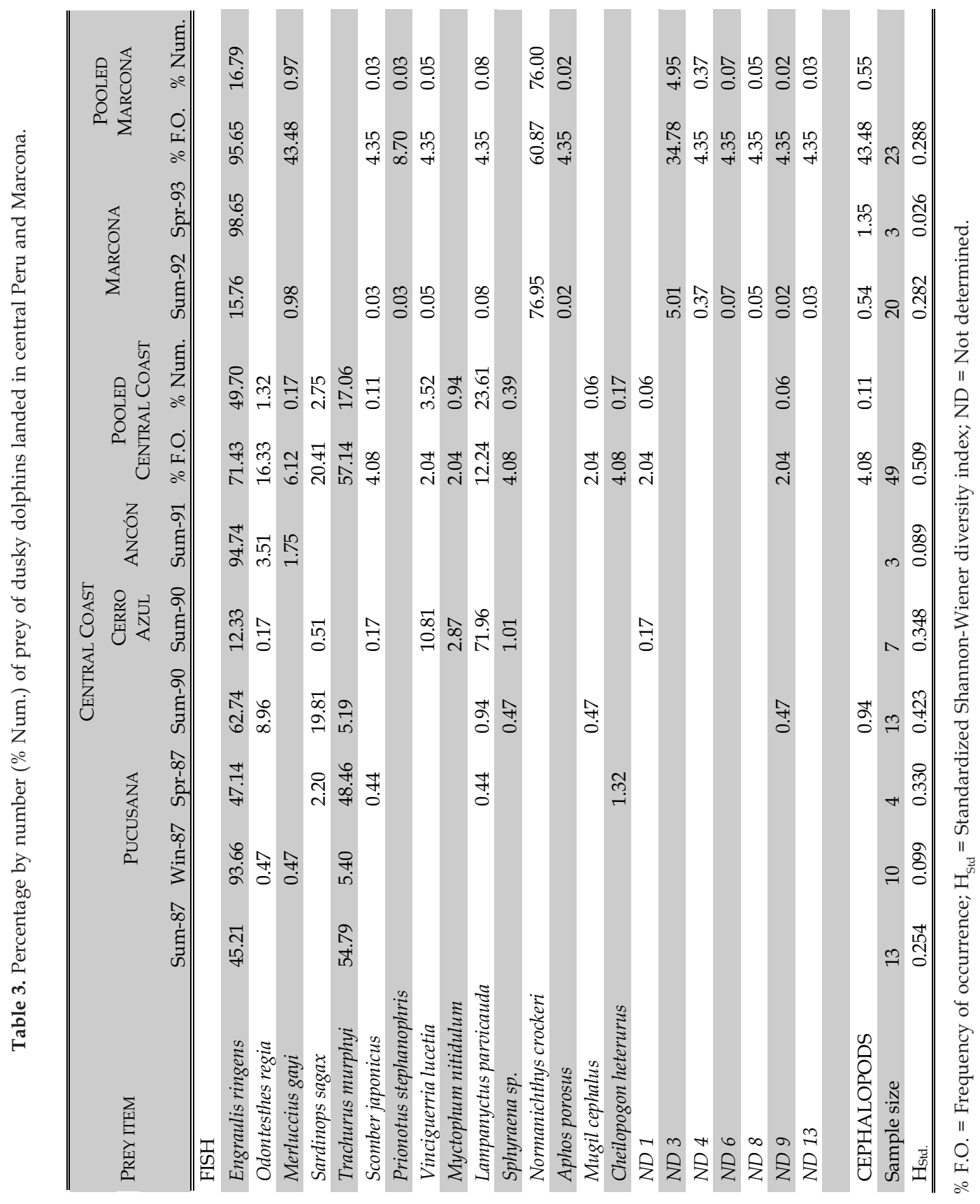


Dusky dolphins landed at Marcona ate mainly fish with some squid present in their diet. Fourteen prey species were recorded (5,966 individuals). The mote sculpin Normanichthys crockeri was the main prey species consumed (76.00\% by number), followed by anchovy ( $16.79 \%)$, among other species. However, the anchovy was the most frequent species consumed ( $95.65 \% \mathrm{FO})$, followed by the mote sculpin (60.87\% FO), hake (43.48\% FO) and squids (43.48\% FO).

There was no statistical difference between the percentage of prey by number consumed in 1987 and in later years $(\mathrm{MW}=64.00, \mathrm{P}>0.1)$, therefore all the samples were pooled for further analysis. For the Peruvian central coast no difference was found in the median consumption of anchovy $(\mathrm{KW}=7.712, \mathrm{P}>0.1, \mathrm{df}=4)$ between sampling periods, with important consumption of this prey in summer as in winter, but with some exceptions (Table 3). Similarly, there were no significant seasonal differences in the consumption of silverside $(K W=5.824, P>0.2, d f=4)$ and slimtail lanternfish $(\mathrm{KW}=6.968, \mathrm{P}>0.1, \mathrm{df}=4)$, in contrast with Inca scad $(\mathrm{KW}=$ 23.243, $\mathrm{P}<0.001, \mathrm{df}=4$ ) as it was absent during two sampling periods. In Marcona there were significant differences in the consumption of anchovy (MW=51.00, $\mathrm{P}<0.05)$ and mote sculpin (MW=51.00, $\mathrm{P}<0.05)$ between spring 1992 and summer 1993, when one of the species predominated by number in each period, respectively.

No statistical differences were found in the central coast among reproductive status with respect to the number of prey $(\mathrm{KW}=6.287, \mathrm{P}>0.1, \mathrm{df}=4)$ and species consumed $(\mathrm{KW}=4.010, \mathrm{P}>0.4, \mathrm{df}=4)$, nor in the number of anchovy $(\mathrm{KW}=2.452, \mathrm{P}>0.6, \mathrm{df}=4)$ and Inca scad $(\mathrm{KW}=6.869$, $\mathrm{P}>0.1, \mathrm{df}=4$ ) consumed. No relationship existed between the number of prey species $\left(r_{s}=0.05, n=42, P>0.7\right)$ and the number of individual fish consumed $\left(r_{s}=0.084, n=\right.$ $42, \mathrm{P}>0.6$ ) with respect to the body length of the dolphin. The standardized Shannon-Wiener index $\left(\mathrm{H}_{\text {std }}\right)$ of diversity for the pooled sample of the central coast was 0.509 (mean $=0.257, \mathrm{SD}=0.126$ ), while for Marcona this index was 0.29. No statistic differences were detected in the diversity of the diet among sampling periods $\left(x^{2}=1.174, \mathrm{P}>0.9, \mathrm{df}=5\right)$ and the combined diversity $\mathrm{H}_{\text {std }}$ for the two areas sampled was $0.474($ mean $=0.284, \mathrm{SD}=0.145)$.

\section{Offshore common bottlenose dolphin}

The diet of offshore common bottlenose dolphins was composed exclusively of fish, accounting for 1157 individuals representing 21 prey species, including the slimtail lanternfish (39.89\% by number), followed by barracuda Sphyraena sp. (13.71\%), Peruvian pilchard $(13.53 \%)$ and the lumptail sarobin Prionotus stephanophrys $(9.75 \%)$, among other species (Table 4$)$. The slimtail lanternfish was also the most frequently consumed species $(45.45 \%$ FO), followed by pilchard (40.91\%), Inca scad $(31.82 \%)$ and anchovy and barracuda, both with $22.73 \%$ FO, amongst other species (Table 4).

Table 4. Percentage by number (\% Num.) of prey of offshore common bottlenose dolphins landed in central Peru.

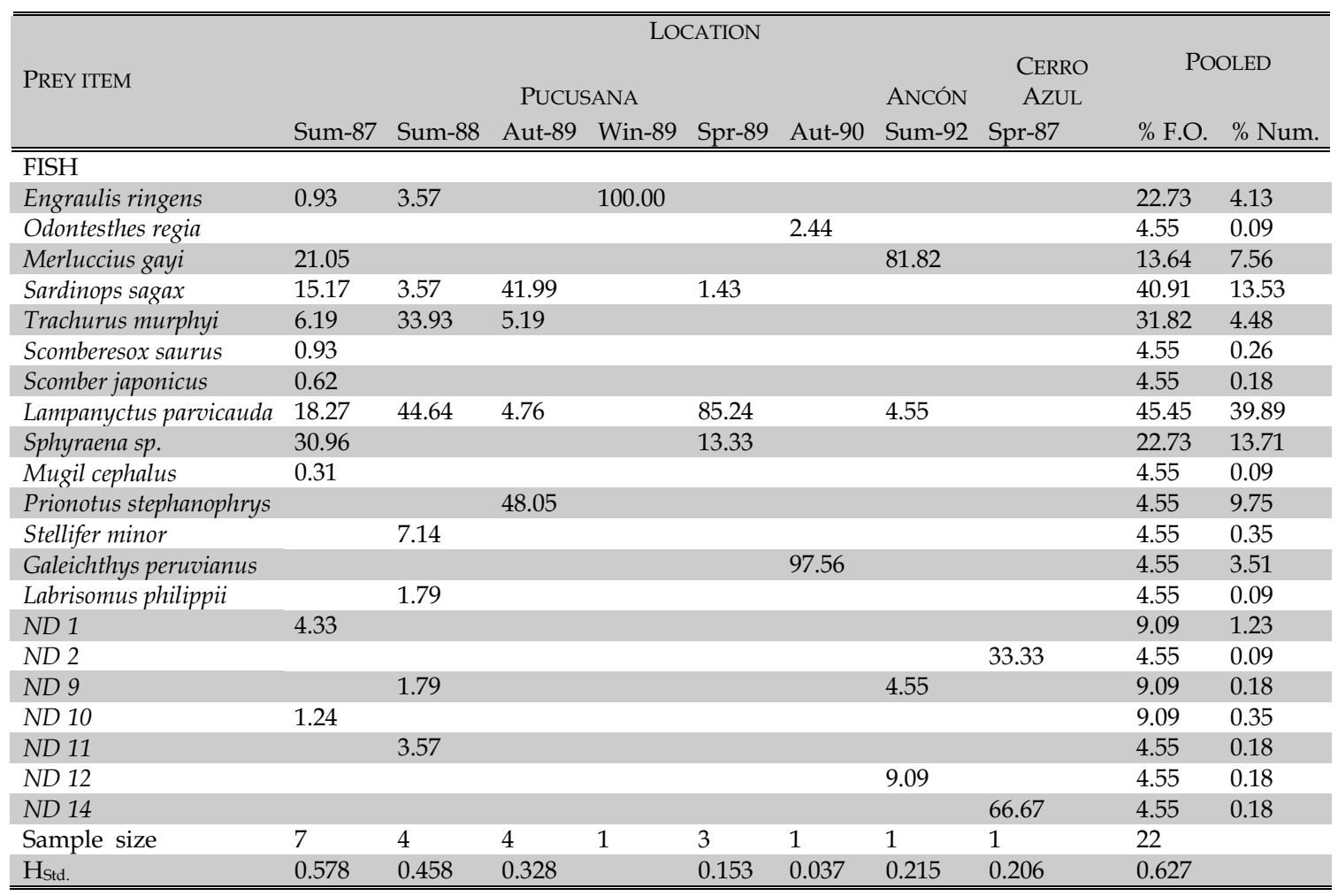

\% F.O. = Frequency of occurrence; $\mathrm{H}_{\mathrm{Std}}=$ Standardized Shannon-Wiener diversity index; ND = Not determined 
There was no statistical difference between the number of prey consumed in 1987 and the rest of samples (MW= 198.00, $\mathrm{P}=0.3$ ), therefore all samples were pooled. No significant differences existed among sampling periods with respect to the mean number of slimtail lanternfish $(\mathrm{KW}=1.272, \mathrm{P}>0.7, \mathrm{df}=3)$, anchovy $(\mathrm{KW}=4.35, \mathrm{P}>0.2$, $\mathrm{df}=3)$, pilchard $(\mathrm{KW}=1.75, \mathrm{P}>0.6, \mathrm{df}=3)$ and Inca scad $(\mathrm{KW}=1.87, \mathrm{P}=0.6, \mathrm{df}=3)$.

The mean number of prey consumed $(K W=6.286, \mathrm{P}>0.15$, $\mathrm{df}=4)$ and the number of prey species $(K W=3.527, \mathrm{P}>0.4$, $\mathrm{df}=4$ ) did not vary significantly among dolphins of different reproductive status. Neither were differences noted (KW tests, $\mathrm{df}=4$ ) in the mean consumption of slimtail lanternfish $(\mathrm{P}>0.2)$, pilchard $(\mathrm{P}>0.4)$, Inca scad $(\mathrm{P}>0.35)$ nor anchovy $(\mathrm{P}>0.2)$ among reproductive status. No significant relationship was apparent between the size (body length) of the dolphin and the number of prey species consumed $\left(r_{s}=0.24, P>0.3, n=18\right)$, nor the number of individuals eaten $\left(r_{S}=0.18, P>0.45, n=18\right)$.

The standardized Shannon-Wiener index of diversity $\left(\mathrm{H}_{\mathrm{std}}\right)$ obtained for the pooled sample was 0.627 (mean= $0.29, \mathrm{SD}=0.20$ ). There were no statistic differences between sampling periods with respect to ShannonWiener indices $\left(x^{2}=1.918, \mathrm{P}>0.95, \mathrm{df}=7\right.$; with $\mathrm{H}_{\max }$ as the expected value: $x^{2}=1.942, \mathrm{P}>0.95, \mathrm{df}=7$ ).

\section{Burmeister's porpoise}

The diet of the Burmeister's porpoise in the central coast of Peru was composed almost exclusively of fish $(98.35 \%)$, represented by eight species and 1070 individuals (Table 5). Anchovy was the main prey by number $(88.88 \%)$ followed by silverside $(6.53 \%)$, amongst other species (Table 5). Anchovy was present in $90.38 \%$ FO of stomach contents, followed by silverside (9.62\% FO) and hake (7.38\% FO).

In Marcona the diet was largely composed of fish (94.78\% by number) followed by squid. Fish accounted for 762 individuals representing eight species. Anchovy was the main prey by number $(77.61 \%)$, followed by the mote sculpin $(8.08 \%)$ and hake $(7.96 \%)$. Anchovy was the most frequent prey $(76.47 \% \mathrm{FO})$, followed by squids (52.94\% FO), hake (35.29\% FO) and mote sculpin (23.53\% FO).

There were no significant differences in the percentage by number of prey consumed in 1987 and the rest of the samples from the central coast $(\mathrm{MW}=22.00, \mathrm{P}>0.29)$, therefore all samples could be pooled. The mean consumption of anchovy $(\mathrm{KW}=9.798, \mathrm{P}>0.10, \mathrm{df}=6)$ and of silversides $(K W=10.601, P>0.10, d f=6)$ did not vary significantly. There were no statistical differences (MW tests) in the consumption of anchovy ( $>0.4)$, hake $(P>0.1)$, mote sculpin $(P>0.8)$ and squids $(P>0.2)$ between spring 1992 and summer 1993 in Marcona.

Porpoises of different reproductive status did not show significant variation with respect to the number of prey $(\mathrm{KW}=6.526, \mathrm{P}>0.15, \mathrm{df}=4)$ nor in the number of prey species consumed $(\mathrm{KW}=7.229, \mathrm{P}>0.1, \mathrm{df}=4)$.

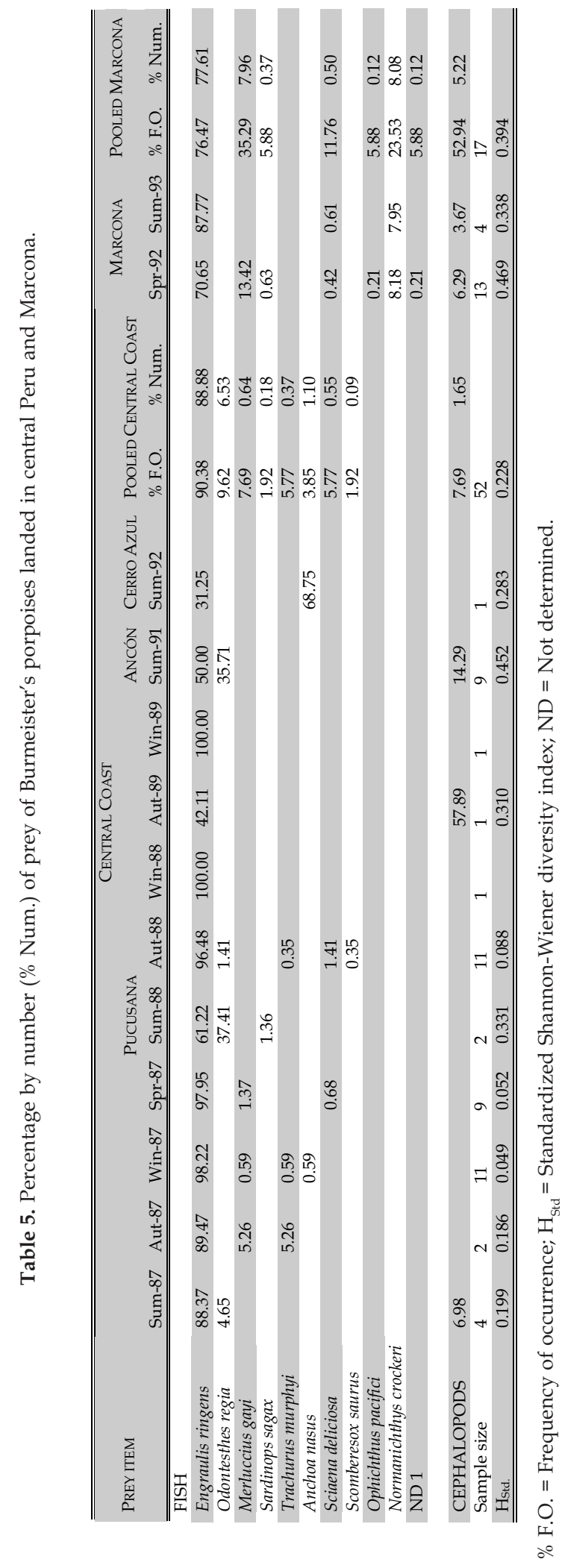


There were no differences among reproductive status with respect to number of anchovy $(\mathrm{KW}=5.281, \mathrm{P}>0.2$, $\mathrm{df}=4)$ nor in the percentage of anchovy consumed (KW= 3.697, $\mathrm{P}>0.4, \mathrm{df}=4)$. While we found a significant relationship between the number of prey consumed and the porpoise's body length $\left(\mathrm{r}_{\mathrm{s}}=0.41, \mathrm{P}=0.01, \mathrm{n}=46\right)$, there was no relation with the number of prey species consumed $\left(r_{s}=0.03, \mathrm{P}>0.8, \mathrm{n}=46\right)$.

The standardized Shannon-Wiener index $\left(\mathrm{H}_{\mathrm{std}}\right)$ of diversity obtained for the pooled sample of the Peruvian central coast was 0.23 (mean=0.177, $\mathrm{SD}=0.145, \mathrm{n}=11$ ), while that obtained for Marcona was a higher $0.39(n=2)$. There were no differences in indices calculated for every period sampled $\left(x^{2}=3.501, \mathrm{P}>0.95, \mathrm{df}=10\right.$; with $\mathrm{H}_{\max }$ as the expected value: $\left.x^{2}=1.699, \mathrm{P}>0.99, \mathrm{df}=10\right)$.

\section{Interspecific relations}

The mean linkage cluster analysis applied to the ratio of contribution of the prey species to the pooled sample of each cetacean studied, using the simplified Morisita's index (Figure 2) shows that the diet of the four cetacean species is very similar, with overlapping trophic niches. The Burmeister's porpoise and the long-beaked common dolphin are closest with a similarity of 0.965 . This cluster joins with the dusky dolphin at a similarity of 0.920 and with the offshore common bottlenose dolphin at 0.873 , Figure2.

The similarity matrix calculated for 1987 among $D$. capensis, L. obscurus and P. spinipinnis did not differ greatly from that obtained for the pooled samples, supporting the methodology used for the pooled data.

A high similarity index (0.915) was found between the general diet of small cetaceans and the industrial fishery of pelagic resources (Niquen and Bouchón, 1995), explainable because anchovy, the main target of industrial fisheries in Peru, is also the main prey of the most abundant small cetaceans species, in the same area. Since cetacean mortality in the artisanal fishery occurs mainly on the continental shelf (Van Waerebeek et al., 1997), it fully overlaps with the industrial fishery for anchovy.

\section{Discussion}

\section{Long-beaked common dolphin}

Epipelagic schooling fish, mainly anchovy, was the main prey of long-beaked common dolphins off central Peru. Other prey were important only during certain sampling periods and comprised neritic (silverside), epipelagic (pilchard and Inca scad), demersal (hake) and mesopelagic (lanternfish and lightfish) fish species. These results are consistent with the findings for the Benguela Current, where common dolphins forage over the shelf on both shallow and deepwater fish (Sekiguchi et al., 1992).
Anchovy schools off Peru are found over the shelf from the surface and $30 \mathrm{~m}$ depth at night and between 30-60 $\mathrm{m}$ during the day (Jordán and Vildoso, 1965). The mesopelagic prey species found are associated with the deep scattering layer and also show diel vertical migrations from surface at night to $400-1000 \mathrm{~m}$ depth during the day (Fitch and Brownell, 1968; Wisner, 1976; Robinson and Craddock, 1983). There is little information on the depth at which this dolphin feeds, but daytime surface feeding (likely on anchovy) has been observed by the authors off central and northern Peru. Gaskin (1982) suggested that common dolphins (Delphinus sp.) make deep dives for food at night and stay near the surface during the day.

El Niño-Southern Oscillation (ENSO) events exert a great influence over pelagic resource fluctuations in the Peru Current (Arntz and Fahrbach, 1996) and thus over prey availability. Anchovy was the main prey species overall, but it was not consumed by common dolphins during all the periods sampled, when alternative prey formed the bulk of the diet. For example, mesopelagic fish during the 1987 El Niño, as well as silversides, hake and sculpins during different periods acquired high importance temporally. This flexibility agrees with an opportunistic feeding behaviour related to local prey availability. The low trophic niche breadth values, unexpected from any opportunistic feeding strategy, are thought to be an artifact produced by the high availability of Peruvian anchovy, which is permanent and abundant during normal years (Pauly and Tsukayama, 1987). Opportunistic feeding behaviour appears to be characteristic for common dolphins around the world, their stomach contents reflecting the local availability of resources (Klinowska, 1981). Off southeast South Africa long-beaked common dolphins

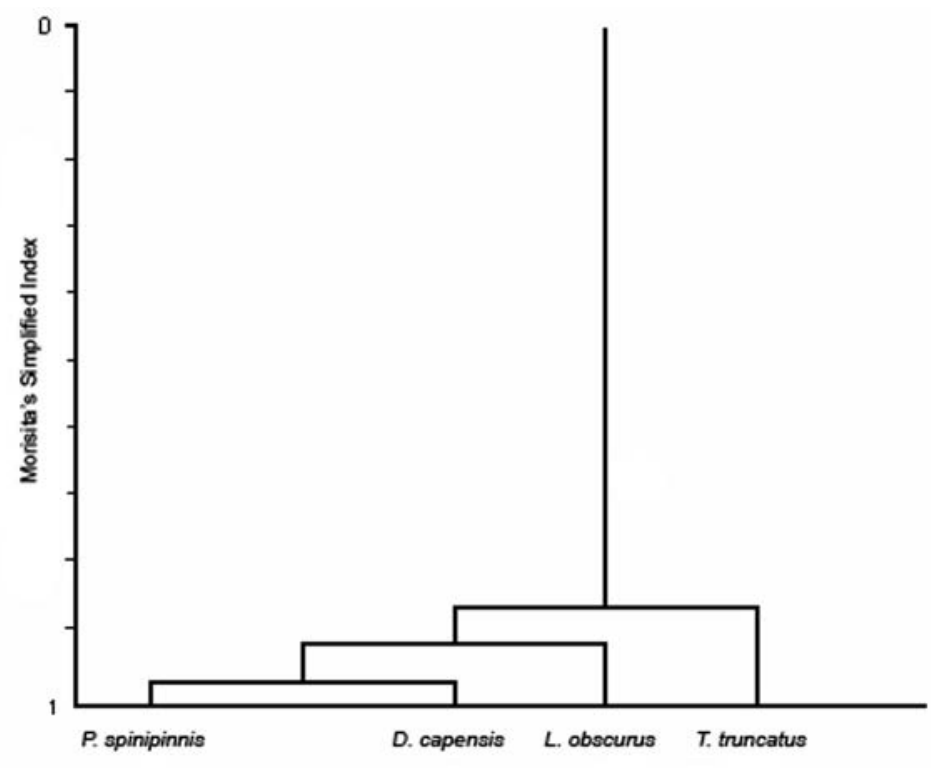

Figure 2. Mean linkage cluster analysis of the diet of four species of small cetaceans from the Peruvian central coast 
forage on the more available prey (Young and Cockcroft, 1994; Sekiguchi et al., 1992). Neritic squids, engraulids, clupeids and mackerels were the main prey in the Benguela Current system (Sekiguchi et al., 1992), while Young and Cockcroft (1994) reported pilchard and myctophids. In the California Current system the species feeds mainly on clupeids, engraulids and hake (Norris and Prescott, 1961; Heyning and Perrin, 1994). Our results for the Peruvian Current ecosystem are consistent with these findings. On the other hand, short-beaked common dolphins, not typically associated with coastal upwelling areas, appear to feed on mesopelagic fish (myctophids), with epipelagic fish as alternative prey in the western North Pacific (Ohizumi et al., 1998; Chou et al., 1995) and mesopelagic fishes (Evans, 1980), carangids and squids (Pascoe, 1986) in the English Channel. Prey differences between both species of common dolphin appear to reflect their diverse habitat (Ohizumi et al., 1998). More productive coastal upwelling environments usually maintain a high biomass of epipelagic schooling fish like anchovies and sardines, while mesopelagic diel migratory fish are more abundant in oceanic waters (Mann and Lazier, 1996; Barnett, 1984).

A higher consumption of anchovy was observed mainly during winter, when anchovy disperses and reaches greater depths (Jordán and Vildoso, 1965; Jordán, 1982). Young and Cockroft (1994) found diet differences in long-beaked common dolphins of different sex, size and reproductive status off South Africa. However, such differences were not found in the present study, possibly due to sampling discontinuity.

\section{Dusky dolphin}

The diet of the dusky dolphin was composed mainly of epipelagic schooling fish (anchovy, sculpins and scads) and mesopelagic fish (lanternfish and lightfish), with an important incidence of neritic fish (silverside) and some demersal fish (hake). Off central Peru dusky dolphins foraged mainly on anchovy, while off Marcona they foraged on sculpins. McKinnon (1994) recorded $92.5 \%$ by weight of anchovy in central Peru in 1985-1986 besides Inca scad, hake and pilchard, but in contrast with the present study he found no mesopelagic species, which suggests changes in the food supply or in the feeding habits. On the Atlantic coast of South America, another engraulid is the main prey of dusky dolphins which forage mainly in the afternoon (Würsig and Würsig, 1980; Crespo et al., 1994; Koen Alonso et al., 1998). Off South Africa the species feeds at any time of the day on both pelagic and deep water fishes such as mackerels, hake and lanternfishes in areas closer to shore and more on the shelf than other cetacean species (Sekiguchi et al., 1992, 19957). Dusky dolphins off Peru have been observed by the present authors feeding on anchovy during both night and day. Stomach contents suggest that they could also feed on mesopelagic fishes at night.

Latitudinal differences in the diet of dusky dolphins between Marcona and Peru's central coast suggest low prey specialization. This becomes evident considering the high occurrence of anchovy in Marcona (96\% FO) and its low percentage by number $(17 \%)$, below mote sculpins, which were completely absent from the central coast sample. Important landings of mote sculpin, a subantarctic schooling fish, have been reported in the area since 1991 (Quiroz et al., 1996). Coincidently, the southern distribution limit for the Northern-Central stock of anchovy is situated at $14^{\circ} \mathrm{S}$ (Pauly and Tsukayama, 1987), i.e. near Marcona, where anchovy becomes scarce. Dusky dolphins then could take advantage of the high availability of sculpins in the area.

Diet composition and trophic niche breadth seems influenced by different food supplies off the central coast and off Marcona, the result of the different oceanographic conditions. Temporal differences in diet were also detected on the central coast during years of strong influence of El Niño (e.g. in 1987). We conclude that dusky dolphins in Peruvian waters are opportunistic schooling fish feeders, foraging on the more abundant and available prey at determined areas and periods, replacing anchovies for sculpins, scads and lanternfishes according their availability.

\section{Offshore common bottlenose dolphin}

The main prey observed were mesopelagic myctophid fish with high diel migration. Van Waerebeek et al. (1990) found anchovy and lanternfish to be the main prey of coastal and offshore Peruvian bottlenose dolphins, respectively. Considering the bathymetric distribution of its main prey (Wisner, 1976; Fitch and Brownell, 1968), offshore common bottlenose dolphins in Peru are thought to feed from the surface down to at least $200 \mathrm{~m}$ depth, but their diel behavior is unknown. However, inshore bottlenose dolphins commonly forage during the day (authors, personal observations).

The values of trophic niche breadth obtained for this species are the highest of the four species analysed in this study and are a reflection of a more varied diet, with six prey species consumed with more than $10 \%$ FO. This figure suggests that the offshore common bottlenose dolphin is an opportunistic and flexible feeder with a wide trophic niche.

\footnotetext{
${ }^{7}$ Sekiguchi, K., Best, P.B. and Klages, N.T.W. (1995) Foraging times of day for three Benguela dolphin species. Eleventh Biennal Conference on the Biology of Marine Mammals, Orlando, USA. (Abstract).
} 


\section{Burmeister's porpoise}

The main prey species of the Burmeister's porpoise was anchovy followed by silverside in the central coast and South Pacific hake and mote sculpin in Marcona. By occurrence, squids were important prey in Marcona. The high amount of anchovy in the diet biased diversity indices as a result of its high availability. However, an important consumption of other prey suggested an opportunistic feeding behaviour on schooling fish and a high diet flexibility, consistent with conclusions from previous work (Reyes and Van Waerebeek, 1995). Porpoises caught off Marcona consumed less anchovy than those from the central coast, but instead consumed more hake, sculpins and squids. Recent nuclear and mt-DNA analysis of Burmeister's porpoises (Rosa et al., 2005) indicates population differences between Peruvian, Chilean and Argentinean individuals, while suggesting genetic heterogeneity also between northern and central Peru. Differences found in diet composition between central Peru and Marcona (separated by ca. $500 \mathrm{~km}$ ) may reflect different feeding habits between subpopulations.

Information gathered from bycatches in Peru indicates that the Burmeister's porpoise is a neritic species. It has been sighted in both, protected bays and open waters relatively close to shore (Read et al., 1988; García-Godos, 1993; Reyes and Van Waerebeek, 1995; Van Waerebeek et al., 2002; Reyes, 2002). Insights obtained from stomach contents collected in the present work confirm such a neritic habitat. Such field data allow a more accurate definition of habitat range than that predicted indirectly from oceanographic information (e.g. Molina-Schiller et al., 2005). A similar inshore distribution has been observed in southern South America where this species also prey on clupeids and gadids (Goodall et al., 1995a, b). On the basis of its prey, sightings and reports of specimens captured in shore seines, Burmeister's porpoise would be the second most neritic forager of the Peruvian small cetaceans after the inshore common bottlenose dolphins (not sampled in this study, but see Van Waerebeek et al., 1990). Despite this, the occurrence of Inca scad and other pelagic prey includes a subtle offshore component or adaptability to occasional prey occurrence in its habitual environment.

\section{Interspecific relations}

The diet of all the species studied was highly related among them, conforming a cluster to a high similarity level of 0.85 (Fig. 2). The long-beaked common dolphin comprises the first cluster with Burmeister's porpoise at a similarity of 0.97 , and not with dusky dolphin, contrary to expectation when considering that in Peru both dolphin species overlap considerably in distribution, and often form mixed schools (authors' observations). However, their diets are still very similar, at a level of 0.875 . The common bottlenose dolphin logically showed the more distant diet because the sample belongs to the large offshore population (Sanino et al. 2005). Likely the identification of cephalopods to species could add more detail to this cluster analysis than cephalopods considered as a single item, although their contribution to the diet was low.

Although the diets of Burmeister's porpoise and dusky dolphin were relatively close off central Peru (simplified Morisitas' Index $=0.780$ ), they were distant in Marcona, at 0.313 of the same index, explainable by a different habitat use further south. The dusky dolphin off Peru shows mainly pelagic, not inshore, habits in relation to coastal waters (Van Waerebeek, 1992a,b), while Burmeister's porpoise is most often sighted nearshore and often occupies, and apparently feeds in, shallow waters of protected bays (Van Waerebeek et al., 2002). Despite this difference, both species feed on anchovy and mote sculpin off Marcona, but probably on different components of these fish stocks.

High similarity in diet between species translates in a low level of diversification in feeding habits and broadly similar foraging strategies. This low diversification would be related to the vast availability of anchovy off Peru (Jordán, 1982; Pauly and Tsukayama, 1987) which can be considered a stabilizing factor for Peruvian small cetaceans under 'normal' oceanographic conditions, keeping interspecific competition for food low, in agreement with theoretical models (Giller, 1984). However, the uncertainty produced by El Niño events off Peru (Arntz and Fahrbach, 1996) sums a selection pressure that would compel small cetaceans to keep an opportunistic feeding strategy.

Despite the high similarity in the diets of these four highly sympatric small cetaceans studied, some differences in feeding habits can be noted. Burmeister's porpoise feeds closer to shore than the other species and with a more demersal foraging component. The distribution range of dusky dolphin and long-beaked common dolphin largely overlaps off Peru, perhaps with some latitudinal differences at their northern limits of distribution. Along the Peruvian coast the dusky dolphin distribution is strongly linked to cool waters and the species is thought to migrate southward when a severe El Niño occurs (Van Waerebeek, 1992; GarcíaGodos, 1993). Offshore bottlenose dolphins occur in deeper water off Peru even beyond the continental slope, as reflected in a different diet based on mesopelagic fish.

Peruvian anchovy has been exploited at a large scale since the 1960s and both overexploitation and fluctuations caused by El Niño have led to the collapse of anchovy predators like guano-producing seabirds (Arnzt and Farbach, 1996). Jahncke et al. (2004), using time series of wind stress, sea surface temperature, seabird population and anchovy landings from central and northern Peru between 1925 to 2000, found that Peruvian guano-producing seabirds reduced their consumption of the available anchovy in the system from $14.2 \%$ before the development of the fishery to $2.2 \%$ afterwards, when fishery captured $85 \%$ of the available anchovy of the system. Together, overfishing and severe El Niño events dramatically reduced the local seabird populations, mainly during the collapse of the anchovy fishery (Duffy et al., 1984; Jahncke et al., 2004). The diet of Peruvian guano-producing seabirds is mainly composed by anchovy and other pelagic species (Jahncke and Goya, 1997; 1998), which suggests that seabirds are positioned trophically very close to the studied small cetaceans. This 
assumption allows us to suppose that small cetaceans could be similarly affected by the anchovy fishery and El Niño as seabirds were. Some evidence supports this hypothesis. Reyes and Van Waerebeek (1995) recorded strandings and emaciated Burmeister's porpoises during the 1982-83 El Niño, suggesting some related effects involved, while food stress during the same event was recorded in dentinal layers of Peruvian dusky dolphins (Manzanilla, 1989). On the other hand, the decrease in dolphin catches, as indicated by decreased landings, during the 1991-92 El Niño may also suggest population movements (García-Godos, 1993), presumably southward as occurs with Peruvian guanoproducing seabirds during El Niño events (Arntz and Fahrbach, 1996).

Based on the relation of prey composition in cetacean species and the Peruvian anchovy, we hypothesize that strong El Niño events would affect firstly and most intensively inshore species and populations in coastal waters of the Peru Current, i.e. Burmeister's porpoises, followed by dusky dolphins and long-beaked common dolphins. Especially the latter species appears somewhat more flexible in habitat and foraging. Offshore common bottlenose dolphins are expected to cope considerably better than the other small cetaceans studied.

\section{Acknowledgements}

We are grateful to Mónica Echegaray, Karina Ontón and Marie-Françoise Van Bressem, for their support during field work. Field research was aided by grants to CEPEC from the Leopold III Fonds voor Natuuronderzoek en Natuurbehoud, United Nations Environment Programme (UNEP), IFAW, IUCN Cetacean Specialist Group/ Species Survival Commission, Cetacean Society International (CSI) and the Whale and Dolphin Conservation Society (WDCS). IGG was supported by Wildlife Conservation Society (WCS) and Concejo Nacional de Ciencia y Tecnología of Peru (CONCYTEC). Data processing and reporting was supported by the International Whaling Commission (IWC Voluntary Fund for small cetacean research) according research proposal SC/52/SM34. We thank Kelly Robertson (SWFSC) and an anonymous reviewer for their constructive comments on the submitted paper.

\section{References}

ARIAS-SCHREIBER, M. (1996) Informe sobre el estado de conocimiento y conservación de los mamíferos marinos en el Perú. Informe Progresivo Instituto del Mar del Perú 38: 3-30.

Arntz, W. E. And Fahrbach, E. (1996) El Niño: Experimento Climático de la Naturaleza. Fondo de Cultura Económica, México.

BAKUn, A. AND WeEKS, S.J. (2008) The marine ecosystem off Peru: What are the secrets of its fishery productivity and what might its future hold? Progress in Oceanography 79:290-299.

BARNETT, M.A. (1984) Mesopelagic fish zoogeography in the central tropical and subtropical Pacific Ocean: species composition and structure at representative locations in three ecosystems. Marine Biology 82(2): 199-208.
BRAINARD, R.E. AND MClain, M.C. (1987) Seasonal and interannual subsurface temperature variability off Peru, 1952-1984. Pages 1445 in Pauly, D. and Tsukayama, I. (Eds) The Peruvian Anchoveta and its Upwelling Ecosystem: Three Decades of Change. ICLARM Studies and Reviews 15. ICLARM, IMARPE, GTZ, Manila.

BRownelL, R.L.JR. AND CLAPHAM, P.J. (1998) Burmeister's porpoise Phocoena spinipinnis (Burmeister, 1865). Pages393-410 in RIDGWAY, S.H. AND HARRISON, R. (Eds), Handbook of Marine Mammals, Vol. 6. Academic Press, London.

Chou, L.S., BRIGHT, A.M. AND YEH, S.Y. (1995) Stomach contents of dolphins (Lissodelphis borealis and Delphinus delphis) from North Pacific Ocean. Zoological Studies 34(3): 206-210.

Crespo, E.A., Nepomnaschy, P., Koen Alonso, M. and García, N. (1994) Análisis preliminar de la dieta de mamíferos marinos sobre la base de contenidos estomacales y heces. Anales 4ta. Reunión de Trabajo de Especialistas en Mamíferos Acuáticos de América del Sur: 75-88.

Duffy, D.C., Hays, C. and Plenge, M.A. (1984) The conservation status of Peruvian seabirds. Pages 245-259 in Croxall, J.P. Evans, P.G.H. AND SCHREIBER, R.W. (Eds) Status and conservation of the world's seabirds. International Council for Bird Preservation, Cambridge.

Evans P.G.H. (1980) Cetaceans in British waters. Mammalian Reviews 10:1-52.

Fitch, J. AND BROWNELL, R. (1968) Fish otoliths in cetacean stomachs and their importance in interpreting feeding habits. Journal of Fishery Research Board of Canada 25(12): 2561-2575.

Frost, K.S. AND LowRY, L.I. (1980) Feeding habits of the ribbon seal (Phoca fasciata) in the Bering Sea in spring. Canadian Journal of Zoology 58: 1601-1607.

GASKIN, D.E. (1982) The Ecology of Whales and Dolphins. Heinemann Educational Books Ltd. London.

García-Godos, A. (1993) Captura estacional de cetáceos menores en la caleta de Ancón. Memoria del X Congreso Nacional de Biología: 273-279.

García-Godos, I. (2001) Patrones morfológicos del otolito sagitta de algunos peces óseos del mar peruano. Boletín del Instituto del Mar del Perú 20: 1-83.

GARCía-Godos, I. (2007) Revisión de las interacciones entre cetáceos y la pesquería marina peruana; perspectivas para la conservación de los cetáceos en Perú. Pages 77-82 in FéLIX, F. (Ed) Memorias del Taller de Trabajo Sobre el Impacto de las Actividades Antropogénicas en Mamíferos Marinos en el Pacífico Sudeste. Bogotá, Colombia, 28-29 de noviembre de 2006. CPPS/PNUMA. Guayaquil, Ecuador.

Goodall, R.N.P., WÜRsig, B., WÜRSIG, M., Harris, G. AND NorRIS, K.S. (1995a) Sightings of Burmeister's porpoise, Phocoena spinipinnis, off southern South America. Pages 297-316 in BJøRGE, A. AND Donovan G.P. (Eds) Biology of the Phocoenids. Report of the International Whaling Commission (special issue 16). Cambridge.

Goodall, R.N.P., NorRis, K.S., HarRIS, G., Oporto, J. AND CASTELLO, H.P. (1995b) Notes on the biology of the Burmeister's porpoise, Phocoena spinipinnis, off southern South America. Pages 317-347 in BJørge, A. And Donovan G.P. (Eds) Biology of the Phocoenids. Report of the International Whaling Commission (special issue 16). Cambridge.

GILLER, P.S. (1984) Community Structure and the Niche. Chapman and Hall Ltd. London.

Heyning, J.E. And PerRIN, W.F. (1994) Evidence for two species of common dolphins (Genus Delphinus) from the eastern North Pacific. Contributions in Science 442: 1-35.

JAHNCKE, J. AND GOYA, E. (1997) Variación latitudinal y estacional en la dieta del guanay (Leucocarbo bougainvillii) y el piquero peruano (Sula variegata) en la costa peruana. Boletín del Instituto del Mar del Perú 16(1): 23-41. 
JAHNCKE, J. AND GoYA, E. (1998) Las dietas del guanay y piquero peruano como indicadoras de la abundancia y distribucion de anchoveta. Boletín del Instituto del Mar del Perú 17:15-34.

JAHNCKE, J., CheCKLEY, D.M. AND Hunt, G.L. (2004) Trends in carbon flux to seabirds in the Peruvian upwelling system: effects of wind and fisheries on population regulation. Fisheries Oceanography 13: 208-223.

JoRDÁN, R. (1982) La anchoveta y su captura frente a las costas de Perú. Monografías Biológicas 2: 51-63.

JORDÁN, R. AND VILDOSO, A. (1965) La anchoveta (Engraulis ringens J.). Conocimiento actual sobre su biología, ecología y pesquería. Informe del Instituto del Mar del Perú 6: 1-52.

KLINOWSKa, M.M. (1991) Dolphins, Porpoises and Whales of the World. The UICN Red Data Book. IUCN, Gland, Switzerland and Cambridge, U.K.

Koen Alonso, M., Crespo, E.A., Garcia, N.A., Pedraza, S.N. and CosCARelLA, M. (1998) Diet of dusky dolphins, Lagenorhynchus obscurus, in waters off Patagonia, Argentina. Fishery Bulletin 96(2): 366-374.

KREBS, C.J. (1989) Ecological methodology. Harper \& Row, Publishers, New York, 654pp.

Majluf, P., Babcock, E.A., Riveros, J.C., Arias-Schreiber, M. AND Alderete, W. (2002) Catch and bycatch of seabirds and marine mammals in the small-scale fishery of Punta San Juan, Peru. Conservation Biology 16(5):1333-1343.

Mann, K.H. and Lazier, J.R.N. (1996) Dynamic of Marine Ecosystems, Biological-physical Interactions in the Oceans. Blackwell Science, Massachusetts.

Manzanilla, S.R. (1989) The 1982-1983 El Niño event recorded in dentinal growth layers in teeth of Peruvian dusky dolphins (Lagenorhynchus obscurus). Canadian Journal of Zoology 67(9):2120-2125.

McKinnon, J. (1994) Feeding habits of the dusky dolphin, Lagenorhynchus obscurus, in the coastal waters of central Peru. Fishery Bulletin 92(3): 569-578.

Molina-Schiller, D., Rosales, S.A. and De Freitas, T.R.O. (2005) Oceanographic conditions off coastal South America in relation to the distribution of Burmeister's porpoise, Phocoena spinipinnis. The Latin American Journal of Aquatic Mammals 4(2):141-156.

NorRis, K.S ANd Prescott, J.H. (1961) Observations of Pacific cetaceans of Californian and Mexican waters. University of California Publications on Zoology 63(4): 291-402.

ÑIQuen, M. AND Bouchón, M. (1995) Información estadística de la pesquería pelágica en la costa peruana, 1981-1993. Informe del Instituto del Mar del Perú 107:1-66.

OHizumi, H., Yoshioka, M., Mori, K.,Miyasaki, N. (1998) Stomach contents of common dolphins (Delphinus delphis) in the pelagic western North Pacific. Marine Mammal Science 14(4): 835-844.

PASCOE, P.L. (1986) Size data and stomach contents of common dolphins, Delphinus delphis, near Plymouth. Journal of the Marine Biology Association, U.K. 66(2):319-322.

Pauly, D. and Tsukayama, I. (1987) On the implementation of management-oriented fishery research: The case of the Peruvian anchoveta. Pages 1-13 in Pauly, D. And Tsukayama, I. (Eds) The Peruvian Anchoveta and its Upwelling Ecosystem: Three Decades of Change. ICLARM Studies and Reviews 15. IMARPE, GTZ, ICLARM, Manila.

Peña, N.J., Mendo, J. and Pellón, J. (1989) Sexual maturity of Peruvian anchoveta (Engraulis ringens), 1961-1987. Pages 132-142 in Pauly, D., Muck, P., Mendo, J. and Tsukayama, I. (Eds) The Peruvian Upwelling Ecosystem: Dynamics and Interactions. Conference Proceedings 18, ICLARM, IMARPE, GTZ, Manila.
Quiroz, M., Zambrano, M. and Cárdenas, F. (1996) El recurso camotillo (Normanichthys crockeri) en la costa sur del Perú. Abril 1995 a enero 1996. Informe Progresivo del Instituto del Mar del Perú 46: 19-29.

Read, A.J., Van Waerebeek, K., Reyes, J.C., Mckinnon, J.S. and LeHMAn, L.C. (1988) The exploitation of small cetaceans in coastal Peru. Biological Conservation 46: 53-70.

REYES, J.C. (2002) Burmeister's porpoise, Phocoena spinipinnis. Pages 177-179 in Perrin, W.F., Würsig, B. AND TheWissen, J.G.M. (Eds) Encyclopedia of Marine Mammals, Academic Press, San Diego.

Reyes, J.C. and Van Waerebeek, K. (1995) Aspects of the biology of Burmeister's porpoise from Peru. Pages 350-364.in Biology of the Phocoenids. BJørge, A. And Donovan G.P. (Eds) Report of the International Whaling Commission (special issue 16). Cambridge.

Robinson, B.H. and CRADdock, J.E. (1983) Mesopelagic fishes eaten by Fraser's dolphin, Lagenodelphis hosei. Fishery Bulletin 81(2): 283-289.

Rosa, S., Milinkovitch, M.C., Van Waerebeek, K. Berck, J., Oporto, J., Alfaro-Shigueto, J., Van Bressem, M.F., Goodall, N. And Cassens, I. (2005) Population structure of nuclear and mitochondrial DNA variation among South American Burmeister's porpoises (Phocoena spinipinnis). Conservation Genetics 6(3): 431 - 443.

RYtHER, J.H. (1969) Photosynthesis and fish production in the sea. Science 166: 72-76.

Sanino, G.P., Van Waerebeek, K., Van Bressem, M.-F. and Pastene, L.A. (2005) A preliminary note on population structure in eastern South Pacific common bottlenose dolphins, Tursiops truncatus. Journal of Cetacean Research and Management 7(1): 65-70.

Sekiguchi, K., Klages, N.T.W. And Best, P.B. (1992) A comparative analysis of the diets of smaller odontocete cetaceans along the coast of Southern Africa in Benguela Trophic Functioning. PAYNE, A.I.L., BrinK, K.H., MANN, K.H. AND Hilborn, R. (Eds) South African Journal of Marine Science 12: 843-861.

SIEgeL, S. (1956) Nonparametric Statistics for the Behavioral Sciences. McGraw-Hill Book Company, New York.

VAn WAerebeEK, K. (1992a) Population identity and general biology of the dusky dolphin Lagenorhynchus obscurus (Gray, 1828) in the Southeast Pacific. Doctoral thesis, Institute for Taxonomic Zoology, University of Amsterdam. 160pp.

VAn WAerebeek, K. (1992b) Records of dusky dolphins Lagenorhynchus obscurus (Gray, 1828) in the eastern South Pacific. Beaufortia 43(4): 45-61.

Van Waerebeek, K. and Read, A.J. (1994) Reproduction of dusky dolphins Lagenorhynchus obscurus from coastal Peru. Journal of Mammalogy 75(4): 1054-1062.

Van Waerebeek, K. AND Reyes, J.C. (1990) Catch of small cetaceans at Pucusana port, central Peru, during 1987. Biological Conservation 51: $15-22$

Van Waerebeek, K. And ReYes, J.C. (1994a) Post-ban small cetacean takes off Peru: a review. Report of the International Whaling Commission (special issue 15): 503-520.

Van Waerebeek, K. and Reyes, J.C. (1994b) Interaction between small cetaceans and Peruvian fisheries in 1988-1989 and analysis of trends. Report of the International Whaling Commission (special issue 15): 495-502.

Van Waerebeek, K., Reyes, J.C., Read, A.J. And McKinnon, J.S. (1990) Preliminary observations of bottlenose dolphins from the Pacific coast of South America. Pages 143-154 in Leatherwood, S. and Reeves, R.R. (Eds) The Bottlenose Dolphin. Academic Press, San Diego. 
Van Waerebeek, K., Van Bressem, M.F., Félix, F., Alfaro-Shigueto, J., García-Godos, A., Chávez-Lisambart, L., Ontón, K., Montes, D. AND BeLLO, R. (1997) Mortality of dolphins and porpoises in coastal fisheries off Peru and Southern Ecuador in 1994. Biological Conservation 81: 43-49.

VAn WAerebeEK, K., SANTILLÁN, L. AND Reyes, J.C. (2002) An unusually large aggregation of Burmeister's porpoise Phocoena spinipinnis off Peru, with a review of sightings from Pacific South America. Noticiario Mensual Museo Nacional de Historia Natural, Chile 350: 3-8.

WISNER, L.R. (1976) The taxonomy and distribution of lanternfishes (Family Myctophidae) of the Eastern Pacific Ocean. NORDA Report 3. Office of Naval Research. St. Louis.
Whitehead, P.J.P., Nelson, G.J. and Wongratana, T. (1988) FAO species catalogue. Vol. 7. Clupeoid fishes of the world (Suborder Clupeoidei). An annotated and illustrated catalogue of the herrings, sardines, pilchards, sprats, shads, anchovies and wolfherrings. Part 2. Engraulididae. FA0 Fisheries Synopsis No. 125, Volume 7, Part 2:305-579.

WÜRSIG, B AND WÜRSIG, M. (1980) Behavior and ecology of the dusky dolphin, Lagenorhynchus obscurus, in the South Atlantic. Fishery Bulletin 77: 871-870.

Young, D.D. and CocKCroft, V.G. (1994) Diet of common dolphins (Delphinus delphis) off southern Africa: opportunism or specialization? Journal of Zoology 234: 41-53. 
